\title{
SIKAP WARGA PUTAT JAYA MENGENAI CITY BRANDING KOTA SURABAYA MELALUI PROGRAM REVITALISASI EKS LOKALISASI DOLLY
}

\author{
Veronica Amelia Maria Pantouw, Brigitta Revia Sandy Fista \\ Universitas Katolik Widya Mandala Surabaya \\ J1. Dinoyo 42-44 Surabaya, 60265 \\ Email : veronicaaaamelia@gmail.com,gita.fiesta@gmail.com
}

\begin{abstract}
Abstrak
Penelitian ini berjudul Sikap Warga Putat Jaya mengenai City Branding Kota Surabaya melalui Program Revitalisasi eks Lokalisasi Dolly. Program Revitalisasi merupakan alat yang digunakan oleh Pemerintah Kota Surabaya dalam melakukan City Branding Kota Surabaya. Program Revitalisasi dilakukan oleh Pemerintah Kota Surabaya dengan menutup Lokalisasi Dolly pada 18 Juni 2014 lalu dan membuat tempat bekas prostitusi tersebut menjadi sebuah Kampung Eduwisata Tematik dan melakukan pemberdayaan pada warga sekitar terdampa melalui beberapa pelatihan guna membantu perekonomian mereka. Tujuan penelitian ini adalah untuk mengetahui sikap Warga Putat Jaya mengenai City Branding Kota Surabaya melalui Program Revitalisasi eks Lokalisasi Dolly. Penelitian ini menggunakan grand theory SOR dengan efek yaitu sikap. Sikap ditinjau dari ketiga komponen, yaitu kognitif, afektif dan konatif yang berdasarkan elemen dari city branding, yakni identitas, komunikasi, dan citra. Penelitian ini merupakan penelitian dengan pendekatan penelitian kuantitatif dan jenis penelitian deskriptif. Peneliti menggunakan metode survei dengan menyebarkan kuesioner kepada 100 responden. Setelah menyebar kuesioner, peneliti menemukan bahwa adanya kecenderungan sikap netral responden mengenai City Branding Kota Surabaya melalui Program Revitalisasi eks Lokalisasi Dolly. Sebagian besar responden menyatakan sikap yang netral, yang berarti tingkat pengetahuan, tingkat afeksi dan tingkat konasi responden mengenai City Branding Kota Surabaya melalui Program Revitalisasi eks Lokalisasi Dolly adalah sedang.
\end{abstract}

Kata kunci : Sikap, City Branding Kota Surabaya, Program Revitalisasi eks Lokalisasi Dolly

\begin{abstract}
Research about Behavior of Putat Jaya Citizens regarding City Branding of Surabaya City through Dolly ExLocalization Revitalization Programs. Revitalization Programs is a tool used by Surabaya City Government in doing City Branding. The revitalization programs was carried out by the Surabaya City Government by closing Localization of Dolly on June 18, 2014 and creating that became a Kampung Eduwisata Tematik and empowering affected residents through several training to help their citizens economies. The purpose of this research is to know the behavior of Putat Jaya Citizens regarding City Branding of Surabaya City through Dolly Ex-Localization Revitalization Programs. This research uses the grand theory of SOR with effect that is behavior. Behavior is divided to three components, which are cognitive, affective and conative based on elements of the city branding, that are identity, communication, and image. This research is a quantitative descriptive research type and used survey methods by distributing questionnaires to 100 respondents. After spreading the questionnaire, researcher found that there is a tendency of neutral attitude of respondents regarding City Branding of Surabaya City through Dolly Ex-Localization Revitalization Programs. Most respondents expressed a neutral behavior, which means the level of knowledge, level of affection and conformity of respondents regarding City Branding of Surabaya City through Dolly Ex-Localization Revitalization Programs is moderate.
\end{abstract}

Key words : Behavior, City Branding of Surabaya City, Dolly Ex-Localization Revitalization Programs

\section{Latar Belakang Masalah}

\section{Teori SOR atau Stimulus Organism Response} merupakan teori yang menjelaskan suatu proses komunikasi yang dimulai dari adanya stimulus berupa pesan yang diterima oleh komunikan. Stimulus atau pesan yang disampaikan kepada komunikan mungkin diterima atau mungkin ditolak. Komunikasi akan berlangsung jika ada perhatian dari komunikan. Proses berikutnya komunikan mengerti. Kemampuan komunikan inilah yang melanjutkan proses berikutnya. Setelah komunikan mengolahnya dan menerimanya, 
maka akan menghasilkan sebuah respon. Respon tersebut dapat meliputi komponenkomponen sikap, opini, perilaku, kognisi, afeksi dan konasi. Menurut teori SOR ini, efek yang ditimbulkan adalah reaksi khusus terhadap stimulus, sehingga seseorang dapat mengharapkan dan memperkirakan kesesuaian antara pesan dan reaksi komunikan (Effendy, 2003: 254-255). Hal terpenting dari proses komunikasi ini berkenaan dengan perubahan sikap yang dihasilkan dan bagaimana cara mengubah sikap komunikan tersebut. Dalam proses perubahan sikap tampak bahwa sikap dapat berubah hanya jika stimulus yang menerpa benar-benar melebihi yang semula (Effendy, 2003: 254-255).

Salah satu bentuk stimulus adalah pesan yang disampaikan oleh pemerintah kepada masyarakatnya berupa pelaksanaan city branding melalui program revitalisasi. Penelitian ini berfokus pada sikap Warga Putat Jaya mengenai City Branding Kota Surabaya melalui Program Revitalisasi eks Lokalisasi Dolly. City branding adalah perangkat pembangunan ekonomi perkotaan yang merupakan praktik-praktik pemasaran kawasan atau lokasi telah lama diterapkan untuk menjual destinasi (wisata), kawasan industri dan perumahan (Yananda, 2014:1). City Branding adalah bagian dari perencanaan kota/perkotaan melalui berbagai upaya untuk membangun diferensiasi dan memperkuat identitas kota agar kota mampu bersaing dengan kota lainnya demi menarik turis, penanam modal, SDM yang andal, industri, serta meningkatkan kualitas hubungan antara warga dengan kota. Melalui city branding suatu tempat (kota, kabupaten dan provinsi) mampu "berbicara" dengan pemangku kepentingan, khususnya warga kota tersebut" (Yananda, 2014:34).

Untuk membangun diferensiasi dan memperkuat identitas kotanya dalam perwujudan city branding, Walikota Surabaya, Tri Rismaharini melakukan program revitalisasi. Program ini dilakukan dengan menutup Lokalisasi Dolly dan membuat kawasan tersebut menjadi kampung eduwisata bersama dengan Humas Pemerintah Kota Surabaya maupun (Satuan Kerja Perangkat Daerah) SKPD yang meliputi Dinas Sosial, Dinas Pendidikan, Dinas Kesehatan, Satpol PP serta menggandeng kelompok anak muda Surabaya yaitu Gerakan Melukis Harapan (GMH) dan Komunitas Bicara Kota Surabaya. Program Revitalisasi ini merupakan alat yang digunakan oleh Pemerintah Kota Surabaya sebagai perwujudan dari city branding Kota Surabaya. Hal terpenting dari adanya penutupan lokalisasi ini disebabkan karena banyak anak kecil di sekitar kawasan Dolly yang telah menerima dampak negatif seperti ikut menggunakan para PSK yang sudah berumur, tak bisa belajar dan terus mengerjakan tugas dengan dentuman keras lagu dari rumahrumah prostitusi. (Jefry, Kasubag Layanan 
Informasi Bagian Humas Pemkot Surabaya 28 April 2017).

Setelah adanya penutupan, wilayah Lokalisasi Dolly menjadi sangat sepi. Banyak warga yang dulunya punya usaha, menutup usahanya. Pada akhirnya angka pengangguran meningkat. Dalam beberapa bulan, sebagian warga menjual harta pribadinya sampai hampir habis. Angka anak putus sekolah pun bertambah, lantaran orangtua mereka tidak sanggup lagi membayar. Sehingga kebijakan Walikota Kota Surabaya Tri Rismaharini menutup dolly sempat membuat kontroversi bagi warga Surabaya maupun warga sekitar dolly sendiri. (Facebook Gerakan Melukis Harapan, diakses 20 Januari 2017). Dalam sebuah perusahaan ataupun pemerintahan, citra merupakan faktor yang penting. Ruslan (2014, 2014:75) menjelaskan bahwa citra positif adalah tujuan utama sekaligus reputasi dan prestasi yang hendak dicapai bagi suatu perusahaan. Untuk dapat menghilangkan image atau citra yang buruk mengenai kota Surabaya yang terkenal dengan lokalisasinya yaitu Dolly dan Jarak, maka Walikota Kota Surabaya Tri Rismaharini perlahan mengubah kawasan tersebut sebagai lokasi wisata tanpa menghilangkan nama Dolly. Menurut Adam, bagian Humas GMH menuturkan bahwa "Pada saat pertama kali Dolly diubah, Walikota Surabaya telah menetapkan bahwa kampung ini digunakan untuk eduwisata, sehingga kami saat ini memang bertujuan untuk kearah branding tempat dan ingin mengenalkan lagi kepada masyarakat luar bahwa Dolly sudah berbeda dengan dahulu kala".

Nama besar Dolly di Jalan Putat Jaya Surabaya akan tetap dipertahankan oleh Pemerintah Kota Surabaya. Nama Dolly dipertahankan mengingat nama itu sudah terlanjur mengindonesia dan bahkan mendunia. Nama Dolly tetap menjadi rekan sejarah, "Sejarah Dolly tidak akan dihapuskan melainkan tetap dimanfaatkan dan kawasannya tetap dipertahankan," ujar Jefry, Humas Kasubag Layanan Informasi Bagian Humas Pemkot Surabaya. Sehingga ketika ada orang yang datang berkunjung, mereka dapat melihat bagaimana keadaan prostitusi terbesar se-Asia Tenggara tersebut. Lokasi ini menjadi unik karena dulunya merupakan tempat prostitusi namun saat ini menjadi sebuah kampung eduwisata. Hal ini berkaitan dengan sebutan brand storytelling yang ada dalam unsur city branding.

Agar eks lokalisasi tetap berkembang, program revitalisasi selanjutnya yang dilakukan oleh Pemerintah Kota Surabaya adalah dengan bersinergi bersama Dinas Sosial, Humas Pemerintah Kota Surabaya dan kelompok anak muda Surabaya yaitu Gerakan Melukis Harapan (GMH) untuk berperan aktif dalam pemberdayaan dan pendampingan warga eks Lokalisasi Dolly. Salah satu gagasan besar pemerintah bersama gerakan 
ini adalah membentuk Dolly menjadi kawasan wisata yaitu Kampung Eduwisata Harapan Dolly yaitu berupa bangunan atau kampung tematik. Kampung Wisata ini terdiri dari beragam Kampung Tematik yang akan ditempatkan di Gang berbeda-beda di sekitar kawasan Jarak-Dolly, diantaranya adalah Kampung Pengolahan Rumput Laut (Orumi), Kampung Seni Mural, Kampung Oleh-oleh (Samijali) dan Kampung Batik (Facebook Gerakan Melukis Harapan, diakses 20 Januari 2017). Pada tahun 2017 Pemerintah Kota bersama gerakan komunitas bicara Surabaya mengadakan Dolly Saiki Fest 2017, kegiatan resmi dibuka oleh Tri Rismaharini, Walikota Surabaya pada 13 Mei 2017 lalu. Dalam acara ini, Risma juga meresmikan Dolly Saiki Point yang merupakan sentra untuk memajang seluruh karya warga eks lokalisasi. Festival ini terdiri dari 23 acara yang berlangsung selama tiga bulan sampai 16 Juli (www.surabaya.go.id, diakses 12 November 2017).

Dalam penelitian ini warga tentunya memiliki sikap yang berbeda-beda dalam menentukan keputusannya dalam mengikutiberagam pelatihan yang diadakan oleh Pemerintah Kota Surabaya dalam rangka memperbaiki ekonomi masyarakat setelah Lokalisasi Dolly yang telah ditutup dan kini diubah oleh Pemerintah Kota Surabaya menjadi Kampung Eduwisata. Sikap menurut Azwar (2016:5) merupakan "Suatu keteraturan tertentu dalam hal perasaan (afeksi), pemikiran (kognisi), dan predisposisi tindakan (konasi) seseorang terhadap suatu aspek di lingkungan sekitarnya. Melalui sikap pula, kita dapat mengetahui sikap seseorang yang berbeda-beda dalam situasi yang sama.

Warga yang pro terhadap program revitalisasi dikarenakan mereka mampu mendapatkan lapangan pekerjaan baru melalui pelatihan Kelompok Usaha Bersama (KUB) dan adanya kampung tematik tersebut. Selain itu dari pihak anak-anak kecil yang tinggal di sekitaran eks lokalisasi sangat berterimakasih kepada Risma bahwa mereka sudah tidak belajar dan mengerjakan tugas dengan dentuman suara musik yang berasal dari rumah-rumah prostitusi. Sebaliknya dari sisi kontra terhadap program revitalisasi adalah dikarenakan mereka yang terdiri dari mantan PSK dan warga sekitar lokalisasi yang merasa sangat dirugikan dari sisi perekonomian, karena keadaan lokalisasi sudah tidak seperti dulu lagi. Peneliti memilih untuk meneliti program revitalisasi eks Lokalisasi Dolly menjadi Kampung Eduwisata Harapan, karena saat ini Tri Rismaharini sebagai pemerintah Kota Surabaya ingin menjadikan kampung ini menjadi objek wisata tersendiri di Surabaya.

Menggunakan teori yang diungkapkan oleh Yananda (2014:57-77) terdapat tiga elemen penting pendukung city branding yang menjadi fokus penelitian yaitu identitas, komunikasi dan citra. Peneliti mengukur 
sikap warga Putat Jaya khususnya warga RW

3, RW 11 dan RW 12 dengan menggunakan ketiga faktor tersebut. Serangkaian pelatihan yang dilaksanakan pemerintah kota bersama Gerakan Melukis Harapan (GMH) pada Kampung Eduwisata Harapan Dolly memiliki sasaran yaitu orang dewasa yang pekerjaan nya telah hilang pasca penutupan Dolly 2014 silam. Berdasarkan situasi tersebut, peneliti mengukur sikap warga yang berusia diatas 18 tahun keatas. Pada usia tersebut, individu sudah dapat dikatakan dewasa dengan ditandainya ijin pembuatan KTP (Kartu Tanda Penduduk). Selain itu mereka juga dirasa telah paham tentang isu-isu revitalisasi dan pemberitaan oleh media massa. Pada masa dewasa seseorang dianggap telah dapat menentukan dan mengembangkan sikap-sikap serta keinginan-keinginan baru secara mandiri. Mereka juga diharapkan dapat mengadakan penyesuaian diri secara mandiri (Hurlock, 1980:246).

Keunikan penelitian ini berada pada lokasi yang dipilih oleh peneliti. Pemilihan lokasi penelitian di Kampung Eduwisata Harapan eks Lokalisasi Dolly disebabkan karena Kota Surabaya yang identik dengan Lokalisasi Dolly nya kini telah diresmikan oleh Pemerintah Kota Surabaya menjadi wisata tematik dengan tidak menghilangkan nama "Dolly" pada kampung tersebut. Warga Putat Jaya khususnya warga RW 3, RW 11 dan RW 12 dipilih oleh peneliti sebagai subjek penelitian karena dalam upaya city branding warga merupakan pemangku kepentingan internal di dalam sebuah kota.

Berdasarkan latar belakang diatas, maka dapat dirumuskan permasalahan dalam penelitian ini yaitu: Bagaimana Sikap Warga Putat Jaya mengenai City Branding Kota Surabaya melalui Program Revitalisasi eks Lokalisasi Dolly?. Metode yang digunakan dalam penelitian ini adalah dengan menggunakan metode survei deskriptif yang bertujuan untuk mendapatkan data berupa sikap warga Putat Jaya mengenai City Branding Kota Surabaya melalui Program Revitalisasi eks Lokalisasi Dolly. Sikap tersebut terbentuk dari serangkaian pelatihan dan event yang telah diadakan oleh pihak Pemerintah Kota Surabaya di Kampung Eduwisata Harapan Dolly yang berada di wilayah eks Lokalisasi Dolly. Luaran dari penelitian ini adalah untuk mengkaji tentang city branding khususnya mengetahui sikap warga menjadi penting karena dapat menjadi bahan evaluasi bagi Pemerintah Kota Surabaya untuk mengetahui apakah City Branding Kota Surabaya yang dilakukan melalui Program Revitalisasi eks Lokalisasi Dolly menghasilkan efek yang positif, netral atau negatif.

\section{Sikap}

Menurut Secord \& Backman (1964) dalam Azwar (2016:6), mendefinisikan sikap sebagai "keteraturan tertentu dalam hal 
perasaan (afeksi), pemikiran (kognisi), dan predisposisi tindakan (konasi) seseorang terhadap suatu aspek di lingkungan sekitarnya. Sikap bersifat evaluatif dan berakar pada nilai yang dianut dan terbentuk dalam kaitannya dalam suatu objek. Dalam proses perubahan sikap tampak bahwa sikap dapat berubah, hanya jika stimulus yang menerpa benar-benar melebihi semula. Perubahan sikap bergantung pada proses yang terjadi pada individu. Ada tiga komponen pembentuk sikap, yaitu :

\section{Komponen Kognitif}

Berisi kepercayaan seseorang mengenai apa yang berlaku atau apa yang benar bagi objek sikap. Sekali kepercayaan terbentuk, maka akan menjadi dasar pengetahuan seseorang mengenai apa yang dapat diharapkan dari objek tertentu. Dengan demikian, interaksi kita dengan pengalaman di masa datang serta prediksi kita mengenai pengalaman tersebut akan lebih mempunyai arti dan keteraturan (Azwar,2016:24-25). Komponen ini berhubungan dengan pikiran atau penalaran yang mempengaruhi proses penambahan pengetahuan pada pikiran manusia, yang menyebabkan dari tidak tahu menjadi tahu, dari tidak mengerti menjadi jelas (Effendy, 2003: 318).

\section{Komponen afektif}

Menyangkut masalah emosional subjektif seseorang terhadap suatu objek sikap. Secara umum, komponen ini disamakan dengan perasaan yang dimiliki terhadap sesuatu. (Azwar,2016:26). Komponen ini berkaitan dengan perasaan. Perasaan akibat dari membaca surat kabar, mendengarkan radio menonton acara televisi atau bioskop, timbul perasaan tertentu pada individu atau masyarakat. Perasaan terpaan media massa itu bisa bermacam-macam seperti senang, tertawa terbahak-bahak, sedih sehingga mencucurkan air mata, takut sampai merinding, perasaan yang hanya bergejolak dalam hati, misalnya marah, benci, kecewa, kesal, penasaran, sayang, gemas, sinis, kecut dan sebagainya (Effendy, 2003: 318).

\section{Komponen konatif}

Menunjukkan bagaimana perilaku atau kecenderungan berperilaku yang ada dalam diri seseorang berkaitan dengan objek sikap yang dihadapinya. Bagaimana orang berperilaku dalam situasi tertentu dan terhadap stimulus tertentu akan banyak ditentukan oleh bagaimana kepercayaan dan perasaannya terhadap stimulus tersebut. Kecenderungan berperilaku secara konsisten, selaras dengan kepercayaan dan perasaan ini membentuk sikap individual (Azwar,2016:27). Komponen ini juga bersangkutan dengan niat, tekat, upaya, usaha yang cenderung menjadi suatu kegiatan atau tindakan. (Effendy, 2003: 318).

Sikap juga memiliki arah, artinya sikap terpilah menjadi dua arah kesetujuan, 
yaitu apakah setuju atau tidak setuju, apakah mendukung atau tidak mendukung, apakah memihak atau tidak memihak terhadap sesuatu atau seseorang sebagai objek. Orang yang setuju, mendukung atau memihak terhadap suatu objek sikap berarti memiliki sikap yang arahnya positif, sedangkan orang yang tidak setuju atau tidak mendukung dikatakan memiliki sikap yang arahnya negatif. Menurut Wawan (2010:34) sifat positif memiliki kecenderungan untuk mendekati, menyenangi, mengharapkan, objek tertentu. Sikap negatif terdapat kecenderungan untuk menjauhi, menghindari, membenci, tidak menyetujui objek tertentu. Pada penelitian ini, peneliti menambahkan sifat sikap netral, karena tidak menutup kemungkinan bahwa Warga Putat Jaya memiliki sifat sikap netral atas program revitalisasi yang dilaksanakan oleh Pemerintah Kota Surabaya.

Selain itu, terdapat faktor yang mempengaruhi sikap terhadap objek sikap, (Azwar, 2016:30-38) adalah Pengalaman pribadi yang dapat menjadi dasar pembentukan sikap, pengalaman pribadi haruslah meninggalkan kesan yang kuat. Kemudian pengaruh orang lain yang dianggap penting, pada umumnya individu cenderung untuk memilki sikap yang konformis atau searah dengan sikap orang yang dianggap penting agar menghindari adanya konflik. Lalu pengaruh kebudayaan, kebudayaan telah mewarnai sikap anggota masyarakatnya, karena kebudayaanlah yang memberi corak pengalaman individu-individu masyarakat asuhannya.

Kemudian media massa, karena pada berita yang disampaikan di media massa seharusnya bersifat factual yang disampaikan secara objektif terkadang dipengaruhi oleh sikap penelitinya, akibatnya berpengaruh juga terhadap sikap konsumennya. Lalu lembaga Pendidikan dan Lembaga Agama, karena konsep moral dan ajaran dari lembaga pendidikan dan lembaga agama sangat menentukan sistem kepercayaan yang dapat mempengaruhi sikap. Serta faktor emosional karena suatu bentuk sikap merupakan pernyataan yang didasari emosi yang berfungsi sebagai semacam penyaluran frustasi atau pengalihan bentuk mekanisme pertahanan ego.

\section{City Branding}

Suatu lokasi atau tempat khususnya di Surabaya, dapat diberi merek yang secara relatif pasti berasal dari nama sebenarnya dari lokasi tersebut. Melakukan branding sebuah lokasi geografis/kota dimaksudkan agar orang sadar atau tahu akan keberadaan lokasi tersebut dan kemudian menimbulkan keinginan untuk mengasosiasikannya. Tujuan dari pemberian merek kota atau lokasi untuk menciptakan kesadaran dan gambaran menyenangkan dari lokasi tersebut sehingga 
akan menarik kunjungan dari perseorangan dan para pembisnis. Dalam mem-branding kota memerlukan beberapa faktor pendukung seperti konsep dan tujuan dari brand sendiri yang telah dibuat oleh pemerintah kota setempat, kemudian bagaimana cara memasarkan brand kota tersebut agar satu kota dapat menjadi objek yang layak dipasarkan.

\section{City branding menurut Yananda} (2014:1) adalah perangkat pembangunan ekonomi perkotaan. City branding merupakan praktik - praktik pemasaran kawasan atau lokasi telah lama diterapkan untuk menjual destinasi (wisata), kawasan indutri dan perumahan. City Branding merupakan bagian dari perencanaan kota/perkotaan melalui berbagai upaya untuk membangun diferensiasi dan memperkuat identitas kota agar kota mampu bersaing dengan kota lainnya demi menarik turis, penanam modal, SDM yang andal, industri, serta meningkatkan kualitas hubungan antara warga dengan kota. Hasil akhir dari city branding adalah membangun citra positif adalah tentang tempat melalui pembangunan spasial dan nonspasial yang membuat perencanaan dan pengelolaan kota menjadi lebih fokus dan terintegrasi pada produksi dan penyampaian pesan yang tepat kepada pemangku kepentingan internal dan eksternal kota. City Branding juga merupakan strategi yang membuat suatu tempat (kota, kabupaten dan provinsi) mampu "berbicara" dengan pemangku kepentingan, khususnya adalah warga. (Yananda, 2014:34)

Sebuah upaya branding pada dasarnya adalah upaya untuk mengisi ruang antara identitas kota dengan citra. Salah satu teknik yang mampu mengisi ruang kosong antara identitas dan citra tersebut adalah mengisinya dengan cerita. Teknik pencitraan ini dikenal dengan sebutan brand storytelling. Sebuah cerita tentang brand memerlukan pesan, konflik, dan diisi dengan karakter. Cerita tentang brand haruslah merupakan cerita yang otentik dan benar-benar terjadi dalam konteks brand yang akan dibangun. Bahan mentah dari cerita dapat bersumber dari pemangku kepentingan dari tempat itu sendiri. Selain bersumber dari pihak internal, sumber cerita juga didapat dari sumber eksternal, yaitu pemuka pendapat di dalam maupun disekitar tempat, partner kerja, pelanggan atau warga dan produk yang dihasilkan oleh kota itu sendiri (Yananda, 2014:83-84). City Branding erat kaitannya dengan Brand image dan reputasi suatu kota yang merupakan penyokong pembangunan ekonomi kota yang kompetitif dan berkelanjutan disini memiliki hubungan yang erat dengan adanya Program Revitalisasi. Program Revitalisasi ini merupakan alat yang digunakan oleh Pemerintah Kota Surabaya sebagai perwujudan dari city branding Kota Surabaya itu sendiri. 
Program revitalisasi adalah upaya untuk meningkatkan nilai lahan/kawasan melalui pembangunan kembali dalam suatu kawasan yang dapat meningkatkan fungsi kawasan sebelumnya. Termasuk pelestarian sebuah kawasan, kegiatan perawatan, pemugaran, serta pemeliharaan bangunan gedung dan lingkungnnya untuk mengembalikan keandalan bangunan tersebut agar sesuai dengan keadaan menurut periode yang dikehendaki. Kemudian suatu kawasan merupakan wilayah yang memiliki fungsi utama atau lindung budaya. Kualitas dari suatu kawasan diharapkan dapat mendukung kelangsungan hidup warganya dan mendukung produktivitas sosial, budaya dan ekonomi dengan tetap mempertahankan kualitas lingkungan fisik dan/atau mencegah kerusakan warisan budaya. Peran masyarakat dalam revitalisasi adalah berbagai kegiatan masyarakat yang merupakan perwujudan kehendak masyarakat untuk memantau dan menjaga ketertiban, memberi masukkan, menyampaikan pendapat dan pertimbangan, dsb. (Peraturan Menteri Pekerjaan Umum Nomor 18/PRT/M/2010) tentang pedoman revitalisasi kawasan Bab I Pasal I).

Terdapat 3 elemen penting dalam membangun sebuah city branding, yaitu:

1. Identitas

Proses city branding terkait dengan pembentukan elemen identitas kota yang berbeda dan mengarahkan sebuah kota tersebut dalam pemasaran. Kemudian identitas tersebut juga merupakan alat yang menjadi dasar dalam pembentukan brand. Dalam hal ini sebuah kota harus mencari dan menggali identitasnya. Kota dengan identitas yang kuat memiliki modal yang besar untuk menjadi kota dengan citra yang kuat.

\section{Komunikasi}

Elemen komunikasi yang dimaksud adalah sebuah identitas yang dikomunikasikan terdiri dari komunikasi primer (terkait dengan intervensi terhadap perancangan kota atau ruang publik dalam ruang kota), kemudian komunikasi sekunder terkait dengan aktivitas pemasaran kota yang disengaja dan terencana seperti iklan, penggunaan logo, slogan, public relation. Komunikasi pada level ini bersifat formal dan melalui saluran yang resmi. Yang terakhir adalah komunikasi tersier yang merupakan pertukaran pesan yang tidak terkontrol seperti laporan media dan perbincangan personal yang tersebar melalui word of mouth (WOM).

3. Citra

Elemen Citra merupakan hasil akhir dari adanya identitas, dan proses komunikasi yang telah dilaksanakan oleh sebuah kota. Citra suatu kota merupakan gambaran yang ada dibenak audiens tentang sebuah kota. Gambaran ini merupakan akumulasi dari pengetahuan (kognitif), pengalaman (konatif) dan keterpaparan melalui berita-berita 
terhadap kota tersebut. Citra juga merupakan cara audiens melalukan penerjemahan (decoding) sinyal yang dikirimkan oleh produk, layanan dan komunikasi yang dilakukan oleh brand. Transimisi dari identitas menuju citra juga dipengaruhi oleh faktor luar yang dapat dianggap sebagai gangguan (noise). Selain ganguan, kompetisi juga menjadi faktor yang menjadikan gap antara identitas dengan citra menjadi semakin jauh (Yananda, 2014: 57-77).

\section{Humas Pemerintah}

Humas pemerintah sering disebut sebagai sekertaris pers, information officer, public affair specialist atau communication specialist yang bertugas menginformasikan pada publik mengenai aktivitas yang dilakukan oleh pemerintah, dalam hal ini humas instansi pemerintah memiliki orientasi yang berbeda dengan instansi swasta. Humas pemerintah juga berurusan dengan publisitas institusi, serta berurusan dengan semua aspek pekerjaan. Kemudian humas juga mengurus pekerjaan advertising atau promosi untuk mendukung kegiatan sosialisasi kebijakan pemerintahan. Melalui unit atau program kerja humas tersebut, pemerintah dapat menyampaikan informasinya atau menjelaskan mengenai kebijaksanaan dan tindakan-tindakan tertentu serta aktivitas dalam melaksanakan tugas-tugas atau kewajiban kepemerintahannya (Sari, 2012:7374).
Pada awal penutupan Lokalisasi Dolly pihak Humas Pemerintah Kota Surabaya mengalami perang isu, dimana banyak berita yang muncul di media seakan-akan memojokkan pemerintah bahwa melalui penutupan ini pemerintah telah menghilangkan mata pencaharian masyarakat Dolly dan sekitarnya. Peran Humas Kota Surabaya tak terlepas dari tugasnya yaitu melakukan pengendalian isu dengan membuat press release yang kemudian disebar kepada media. Selain melakukan pengendalian isu, humas pemerintah juga melakukan pendataan kartu keluarga terhadap anak-anak yang terdampak dari adanya Lokalisasi Dolly. Selain itu Humas Pemerintah Kota Juga ikut melakukan publikasi event Dolly Saiki Fest yang berlangsung pada bulan Mei-Juni melalui akun instagram Surabaya (Jefry, Kasubag Layanan Informasi Bagian Humas Pemkot Surabaya, 28 April 2017).

\section{Metode Penelitian}

Dalam penelitian ini akan menggunakan pendekatan kuantitatif dengan jenis penelitian deskriptif untuk mengukur sikap. Jenis penelitian deskriptif karena sesuai dengan tujuan penelitian ini, yaitu untuk menggambarkan populasi yang ingin diteliti, dan berfokus pada apa yang terjadi saat ini, serta terdiri dari satu variabel (Kriyantono, 2006:59). Pada penelitian ini akan menggunakan metode survei (survey research). Penelitian survei adalah penelitian 
yang mengambil sampel dari satu populasi dan menggunakan kuesioner sebagai alat pengumpul data yang pokok. Pengerjaan bentuk survei ini akan menggunakan kuesioner yang akan dibagikan kepada Warga Putat Jaya di RW 3, RW 11, dan RW 12 Surabaya.

Peneliti hanya menggunakan satu variabel atau variabel tunggal, yaitu sikap warga mengenai upaya City branding Kota Surabaya melalui Program Revitalisasi eks Lokalisasi Dolly, dengan melakukan pengukuran sikap melalui teori city branding oleh Yananda (2014: ), sebagai berikut : Identitas, yaitu alat yang menjadi dasar dalam pembentukan brand. Kemudian komunikasi adalah sebuah identitas yang dikomunikasikan terdiri dari komunikasi primer, kemudian komunikasi sekunder, dan komunikasi tersier. Citra yakni hasil akhir dari adanya identitas, dan proses komunikasi yang telah dilaksanakan oleh sebuah kota.

Peneliti menggunakan populasi dari Warga Putat Jaya khususnya warga di RW 3, RW 11, dan RW 12 berdasarkan data monografi Kelurahan Putat Jaya 2017 dengan total 6015 orang. Responden yang menjadi sampel dalam penelitian ini adalah warga di Putat Jaya, dengan menggunakan teknik Probability Sampling dalam pengambilan sampel. Peneliti akan menggunakan teknik purposive sampling, dimana Pemilihan subjek atau orang-orang terpilih dalam sampel purposif harus sesuai dengan ciri-ciri khusus yang dimiliki oleh sampel. Peneliti juga mengkolaborasikan dengan quota sampling untuk menentukan porsi per RW (Silalahi, 2012:271-273).

Untuk menguji validitas pada penelitian ini akan menggunakan teknik Product Moment dengan menggunakan SPSS untuk mengujinya. Setelah uji validitas dilakukan dan dinyatakan valid, maka kemudian akan dilakukan uji reliabilitas terhadap kuesioner dengan melihat jawaban responden menggunak'an rumus Alpha Cronbach. Teknik analisis data yang akan peneliti gunakan berupa statistik deskriptif melalui tabel distribusi frekuensi dan tabulasi silang. Dalam penelitian ini, peneliti mengolah data secara bertahap yang meliputi pemrosesan data (data processing), penyuntingan (editing), pengkodean (coding), dan tabulasi dengan penjelasan sebagai berikut (Silalahi, 2012:320-336).

\section{Gambaran Umum Subyek Penelitian}

Subjek dalam penelitian ini adalah Warga Putat Jaya. Menurut Undang-Undang Dasar (UUD) tahun 1945 Pasal 26 ayat 1 menyebutkan bahwa warga adalah orangorang bangsa Indonesia asli dan orang-orang bangsa lain yang disahkan dengan undangundang sebagai warga Negara. Kemudian menurut Yananda (2014:34) warga merupakan pemangku kepentingan yang 
berada di suatu kota, kabupaten, maupun provinsi.

Data Monografi Kelurahan Putat Jaya tahun 2017 menyatakan bahwa jumlah kepala keluarga adalah sebanyak $13.442 \mathrm{KK}$, jumlah penduduk menurut jenis kelamin laki-laki sebanyak 24.431 orang dan perempuan sebanyak 24.225 orang, dan total keseluruhan penduduk sebanyak 48.656 orang. Kelurahan Putat Jaya memiliki jumlah penduduk menurut kewarganegaraan yakni WNI lakilaki sebanyak 24.431 orang dan perempuan sebanyak 24.225 orang dan jumlah seluruhnya adalah 48.456 orang, sedangkan untuk WNA belum ada. Subjek pada penelitian ini adalah Warga Putat Jaya khususnya warga RW 3, RW 11, dan RW 12 Kelurahan Putat Jaya berjumlah keseluruhan 6015 jiwa dari total keseluruhan warga yang berada dalam Kelurahan Putat Jaya.

Kemudian jumlah penduduk menurut agama Kelurahan Putat Jaya, para warga menganut berbagai macam agama yakni Islam, Kristen, Katholik, Hindu, Budha. Agama Islam merupakan agama yang dianut oleh mayoritas warga Kelurahan Putat Jaya, sedangkan agama Kristen terbanyak setelah agama Islam, dilanjutkan dengan agama Katolik, Hindu dan Budha. Pada jumlah penduduk menurut usia, Kelurahan Putat Jaya mengelompokkan menjadi dua kelompok yaitu, kelompok pendidikan dan kelompok tenaga kerja. Usia 19 tahun keatas merupakan angka paling tinggi dalam jumlah penduduk pada kelompok pendidikan dengan jumlah 30.884 orang. Lalu pada kelompok tenaga kerja, usia 27-40 tahun merupakan angka paling tinggi dalam jumlah penduduk menurut usia kelompok tenaga kerja dengan jumlah 12.692 orang. Jumlah Penduduk Menurut Pekerjaan, terdapat beragam jenis pekerjaan yang dimiliki oleh Warga Putat Jaya, diantaranya ialah Pegawai Negeri Sipil, TNI, Polri, Swasta, Wiraswasta, Pelajar/ Mahasiswa, Pedagang, Ibu Rumah Tangga.

\section{Uji Validitas dan Reliabilitas}

Validitas menunjukkan sejauh mana suatu alat ukur itu mampu mengukur apa yang ingin diukurnya. Dalam penelitian ini, validitas kuesioner ditentukan dengan menggunakan Corrected Item Total Correlation. Apabila hasil Corrected Item Total Correlation dengan skor totalnya $\geq 0,30$ maka item pernyataan tersebut dinyatakan valid dan sebaliknya apabila hasil Corrected Item Total Correlation yang dihasilkan < 0,30 maka item pernyataan tersebut dinyatakan tidak valid. Uji validitas pada penelitian ini menggunakan bantuan dari program SPSS for windows (Azwar, 2003:158). Sedangkan kehandalan suatu jawaban dari kuesioner dapat diketahui melalui uji reliabilitas. Adapun cara yang digunakan untuk menguji reliabilitas kuesioner dalam penelitian ini adalah menggunakan rumus koefisien Alpha Cronbach. Apabila hasil koefisien Alpha melebihi dari tingkat signifikan 0,60 maka 
kuesioner tersebut reliabel. Apabila hasil koefisien Alpha kurang dari tingkat signifikan 0,60 maka kuesioner tersebut tidak reliabel (Ghozali,2002:132).

\section{Analisa Data}

Pemilihan identitas responden yang peneliti buat pada kuesioner disesuaikan dengan hubungan hubungan dari sikap Warga Putat Jaya. Hubungan yang dimaksud adalah jenis kelamin, usia, agama, asal daerah, pendidikan terakhir, dan pekerjaan akan mempengaruhi pembentukan sikap.

Tabel IV.6.

Deskripsi Identitas Responden Berdasarkan Jenis Kelamin

\begin{tabular}{|c|c|c|c|}
\hline No. & Jenis kelamin & Jumlah & Persentase (\%) \\
\hline 1. & Laki-laki & 40 & 40,0 \\
\hline 2. & Perempuan & 60 & 60,0 \\
\hline & Total & 100 & 100,0 \\
\hline
\end{tabular}

Sumber : Olahan Peneliti

Tabel di atas menunjukkan total responden dilihat dari jenis kelamin, dapat diketahui bahwa mayoritas responden dalam penelitian ini berjenis kelamin perempuan yaitu sebanyak 60 orang sedangkan sisanya sebanyak 40 orang berjenis kelamin laki-laki. Berdasarkan penelitian yang dilakukan peneliti, mayoritas responden yang merupkan warga Putat Jaya khususnya RW 3, 11, dan 12 berjenis kelamin perempuan.
Tabel IV.7.

\section{Deskripsi Identitas Responden}

Berdasarkan Usia

\begin{tabular}{|c|c|c|c|}
\hline No. & Usia & Jumlah & $\begin{array}{c}\text { Persentase } \\
(\%)\end{array}$ \\
\hline 1. & $\begin{array}{l}18-40 \\
\text { tahun }\end{array}$ & 66 & 66.0 \\
\hline 2. & $\begin{array}{l}41-60 \\
\text { tahun }\end{array}$ & 34 & 34.0 \\
\hline & Total & 100 & 100,0 \\
\hline
\end{tabular}

Sumber : Olahan Peneliti

Tabel di atas menunjukkan total responden dilihat dari usia, dapat diketahui bahwa responden yang berada di RW 3, RW 11, dan RW 12 Putat Jaya yang terdampak dari adanya Penutupan Lokalisasi Dolly yang telah menjadi Kampung Eduwisata Tematik mayoritas berusia 18-40 tahun yaitu sebanyak 66 orang, dan sisanya berusia 41-60 tahun yaitu sebanyak 34 orang.

Tabel IV.8.

Deskripsi Identitas Responden Berdasarkan Agama

\begin{tabular}{|c|c|c|c|}
\hline No. & Agama & Jumlah & Persentase (\%) \\
\hline 1 & Islam & 96 & 96.0 \\
\hline 2 & Kristen & 4 & 4.0 \\
\hline & Total & 100 & 100,0 \\
\hline
\end{tabular}

Dilihat dari agama, dapat diketahui bahwa 96\% mayoritas responden dalam penelitian ini beragama islam dan sisanya sebanyak $4 \%$ beragama kristen. Hal ini sejalan dengan Data Monografi Kelurahan Putat Jaya tahun 2017 yang menyatakan bahwa jumlah penduduk menurut agama adalah mayoritas beragama islam yaitu sebanyak 42.328 orang, lalu 
dilanjutkan dengan agama kristen sebanyak 4.529 orang, agama katolik sebanyak 1.061 orang, Hindu sebanyak 73 orang dan Budha sebanyak 57 orang.

Tabel IV.9.

Deskripsi Karakteristik Responden Berdasarkan Asal Daerah

\begin{tabular}{|c|c|c|c|}
\hline No. & $\begin{array}{c}\text { Asal } \\
\text { daerah }\end{array}$ & Jumlah & $\begin{array}{c}\text { Persentase } \\
(\%)\end{array}$ \\
\hline 1. & Surabaya & 87 & 87.0 \\
\hline 2. & Lainnya & 13 & 13.0 \\
\hline & Total & 100 & 100,0 \\
\hline
\end{tabular}

Sumber : Olahan Peneliti

Tabel di atas menunjukkan total responden dilihat dari asal daerah, dapat diketahui bahwa responden yang berada di RW 3, RW 11, dan RW 12 Putat Jaya yang terdampak dari adanya Penutupan Lokalisasi Dolly yang telah menjadi Kampung Eduwisata Tematik mayoritas berasal dari Surabaya yaitu sebanyak 87 orang dan sisanya sebanyak 13 orang berasal dari selain Surabaya, sisa ini berasal dari Gresik, Madura, Madiun, Pekalongan, Malang, Blitar, Probolinggo, Pasuruan, Tulungagung, Banyuwangi.

Tabel IV.10.

Deskripsi Identitas Responden Berdasarkan Pendidikan Terakhir

\begin{tabular}{|c|l|c|c|}
\hline No. & Pendidikan & Jumlah & Persentase (\%) \\
\hline 1. & SD & 14 & 14.0 \\
\hline 2. & SMP & 37 & 37.0 \\
\hline 3. & SMA & 48 & 48.0 \\
\hline 4. & Sarjana & 1 & 1.0 \\
\hline \multicolumn{2}{|c|}{ Total } & 100 & 100,0 \\
\hline \multicolumn{2}{|c|}{ Sumber : Ol } \\
\hline
\end{tabular}

Sumber : Olahan Peneliti

Tabel di atas menunjukkan total responden dilihat dari Pendidikan Terakhir, dapat diketahui bahwa responden yang berada di RW 3, RW 11, dan RW 12 Putat Jaya yang terdampak dari adanya Penutupan Lokalisasi Dolly yang telah menjadi Kampung Eduwisata Tematik mayoritas berpendidikan SMA yaitu sebanyak 48 orang, kemudian responden berpendidikan SMP sebanyak 37 orang, responden berpendidikan SD dan yang berpendidikan Sarjana hanya ada 1 orang saja.

Tabel IV.11.

Deskripsi Identitas Responden Berdasarkan Pekerjaan

\begin{tabular}{|c|c|c|c|}
\hline No. & Pekerjaan & Jumlah & $\begin{array}{c}\text { Persentase } \\
(\%)\end{array}$ \\
\hline 1. & Karyawan & 22 & 22.0 \\
\hline 2. & Wirausaha & 16 & 16.0 \\
\hline 3. & IRT & 36 & 36.0 \\
\hline 4. & Lain-lain & 26 & 26.0 \\
\hline & Total & 100 & 100,0 \\
\hline
\end{tabular}

Tabel di atas menunjukkan total responden dilihat dari asal daerah, dapat diketahui bahwa responden yang berada di RW 3, RW 11, dan RW 12 Putat Jaya yang terdampak dari adanya Penutupan Lokalisasi Dolly yang telah menjadi Kampung Eduwisata Tematik mayoritas bekerja sebagai Ibu Rumah Tangga (IRT) yaitu sebanyak 36 orang, responden yang bekerja selain menjadi karyawan, wirausaha dan Lain-lain sebanyak 26 orang, kemudian responden bekerja sebagai karyawan sebanyak 22 orang dan responden yang bekerja sebagai wirausaha sebanyak 16 orang. 
Tabel IV.12.

Deskripsi Komponen Kognitif Berdasarkan Elemen Identitas

\begin{tabular}{|c|c|c|c|c|c|c|c|c|c|c|}
\hline \multirow{2}{*}{\multicolumn{3}{|c|}{ Identitas Kognitif }} & \multicolumn{5}{|c|}{ Jawaban Responden } & \multirow{2}{*}{$\begin{array}{c}\text { Total } \\
\text { Frek } / \\
\%\end{array}$} & \multirow{2}{*}{$\begin{array}{l}\text { Total } \\
\text { Score }\end{array}$} & \multirow[t]{2}{*}{ Mean } \\
\hline & & & \multirow{2}{*}{$\begin{array}{c}\text { STS } \\
0\end{array}$} & \multirow{2}{*}{$\begin{array}{l}\text { TS } \\
0\end{array}$} & \multirow{2}{*}{$\begin{array}{l}\mathbf{N} \\
7\end{array}$} & \multirow{2}{*}{$\begin{array}{l}S \\
64\end{array}$} & \multirow{2}{*}{$\begin{array}{l}\text { SS } \\
29\end{array}$} & & & \\
\hline ikog1 & Saya mengetahui tentang identitas Kota & Frek & & & & & & 100 & 422 & 4.22 \\
\hline & Surabaya terkenal dengan Dolly. & $\%$ & 0 & 0 & 7 & 64 & 29 & 100 & & \\
\hline ikog2 & Saya mengetahui penutupan Lokalisasi & Frek & 0 & 0 & 1 & 75 & 24 & 100 & 423 & 4.23 \\
\hline & Dolly oleh Pemerintah Kota Surabaya. & $\%$ & 0 & 0 & 1 & 75 & 24 & & & \\
\hline ikog3 & Saya mengetahui tentang upaya & Frek & 0 & 0 & 2 & 74 & 24 & 100 & 422 & 4.22 \\
\hline & $\begin{array}{l}\text { pembangunan kembali Kawasan eks } \\
\text { Lokalisasi Dolly oleh Pemerintah Kota } \\
\text { Surabaya. }\end{array}$ & $\%$ & 0 & 0 & 2 & 74 & 24 & 100 & & \\
\hline ikog4 & Saya mengetahui keadaan eks Lokalisasi & Frek & 0 & 0 & 3 & 70 & 27 & 100 & 424 & 4.24 \\
\hline & $\begin{array}{l}\text { Dolly Surabaya saat ini yang telah dirubah } \\
\text { menjadi Kampung Eduwisata Harapan Dolly. }\end{array}$ & $\%$ & 0 & 0 & 3 & 70 & 27 & 100 & & \\
\hline ikog5 & Saya mengetahui perubahan tentang eks & Frek & 0 & 23 & 28 & 37 & 12 & 100 & 338 & 3.38 \\
\hline & $\begin{array}{l}\text { lokalisasi Dolly Surabaya oleh pemerintah } \\
\text { kota merupakan upaya untuk perwujudan } \\
\text { dari perbaikan citra atau gambaran dari Kota } \\
\text { Surabaya. }\end{array}$ & $\%$ & 0 & 23 & 28 & 37 & 12 & 100 & & \\
\hline Rata-r & ta Komponen Kognitif berdasarkan Elemen & Identit & & & & & & & & 4,06 \\
\hline
\end{tabular}

Berdasarkan Tabel IV.12. di atas, nilai rata-rata sikap responden pada komponen kognitif yang berdasarkan elemen identitas adalah 4,06 yang menandakan positif, yang berarti tingkat pengetahuan responden pada komponen kognitif berdasarkan elemen identitas adalah tinggi. Hal ini disebabkan pada komponen kognitif mayoritas responden mengetahui mengenai identitas Kota Surabaya yang terkenal dengan Dolly, mereka juga mengetahui penutupan Lokalisasi Dolly yang dilakukan oleh Pemerintah Kota Surabaya beserta perubahannya saat ini yang telah dirubah menjadi Kampung Eduwisata Tematik, responden juga mengetahui perubahan yang dilakukan oleh pemerintah kota sedemikian rupa juga bertujuan untuk untuk perwujudan dari perbaikan citra atau gambaran dari Kota Surabaya. Mayoritas warga Putat Jaya mengetahui tentang identitas Kota Surabaya terkenal dengan Dolly. Hal ini dikarenakan mayoritas Warga Putat Jaya berasal dari Surabaya sehingga mereka mengetahui cerita tentang Lokalisasi Dolly yang berada di wilayah tempat tinggal mereka. Lokalisasi Dolly juga telah berdiri sejak lama dan menjadi identik bagi Kota Surabaya itu sendiri. Berdasarkan wawancara peneliti dengan Jarwo Susanto salah satu warga Dolly, ia mengatakan bahwa "Jangan ngaku tahu Indonesia kalau tidak tahu Bali dan Dolly di Surabaya”. 
Tabel IV.13.

Deskripsi Komponen Kognitif Berdasarkan Elemen Komunikasi

\begin{tabular}{|c|c|c|c|c|c|c|c|c|c|c|}
\hline & Identitas konatif & & & wabs & Res & onde & & Total & Total & Mean \\
\hline & & & & & & & & & & \\
\hline Kom & Saya mengetahui adanya Kampung Eduwisata & Frek & 3 & 58 & 1 & 26 & 12 & 100 & 286 & 2.86 \\
\hline kog1 & $\begin{array}{l}\text { Harapan Dolly Surabaya melalui media sosial milik } \\
\text { Pemerintah Kota Surabaya (instagram dan } \\
\text { facebook).diadakan oleh Pemerintah Kota Surabaya } \\
\text { bersama Gerakan Melukis Harapan (GMH) di salah } \\
\text { satu Kelompok Usaha Bersama (KUB) yang ada di } \\
\text { Kampung Eduwisata Harapan eks Lokalisasi Dolly } \\
\text { Surabaya. }\end{array}$ & $\%$ & 3 & 58 & 1 & 26 & 12 & 100 & & \\
\hline Kom & Saya mengetahui adanya penutupan Lokalisasi Dolly & Frek & 0 & 43 & 6 & 33 & 18 & 100 & 326 & 3.26 \\
\hline Kog2 & $\begin{array}{l}\text { dan Perubahannya menjadi Kampung Eduwisata } \\
\text { Harapan Dolly Surabaya melalui media massa } \\
\text { konvensional (Koran/TV). }\end{array}$ & $\%$ & 0 & 43 & 6 & 33 & 18 & 100 & & \\
\hline Kom & Saya mengetahui adanya penutupan Lokalisasi Dolly & Frek & 2 & 59 & 4 & 21 & 15 & 100 & 286 & 2.86 \\
\hline Kog3 & $\begin{array}{l}\text { dan Perubahannya menjadi Kampung Eduwisata } \\
\text { Harapan Dolly Surabaya melalui situs berita online }\end{array}$ & $\%$ & 2 & 59 & 4 & 21 & 15 & 100 & & \\
\hline Kom & Saya mengetahui adanya penutupan Lokalisasi Dolly & Frek & 0 & 13 & 5 & 61 & 21 & 100 & 390 & 3.90 \\
\hline Kog 4 & $\begin{array}{l}\text { dan Perubahannya menjadi Kampung Eduwisata } \\
\text { Harapan Dolly Surabaya dari perbincangan warga } \\
\text { sekitar. }\end{array}$ & $\%$ & 0 & 13 & 5 & 61 & 21 & 100 & & \\
\hline Kom & Saya mengetahui adanya penutupan Lokalisasi Dolly & Frek & 2 & 32 & 6 & 43 & 17 & 100 & 341 & 3.41 \\
\hline Kog5 & $\begin{array}{l}\text { dan Perubahannya menjadi Kampung Eduwisata } \\
\text { Harapan khas Dolly Surabaya melalui sosialisasi dari } \\
\text { Pemerintah Kota Surabaya. }\end{array}$ & $\%$ & 2 & 32 & 6 & 43 & 17 & 100 & & \\
\hline Rata-1 & Komponen Kognitif berdasarkan Elemen Komunik: & & & & & & & & & 3.26 \\
\hline
\end{tabular}

Sumber: Olahan Peneliti

Berdasarkan Tabel IV.13. di atas, nilai rata-rata sikap responden pada komponen kognitif yang berdasarkan elemen komunikasi adalah 3,26 yang menandakan netral. Hal ini berarti tingkat pengetahuan responden pada komponen kognitif berdasarkan elemen komunikasi adalah sedang. Mayoritas responden tidak dekat dengan media baru seperti Instagram, Facebook, dan situs berita online. Mayoritas responden tidak pernah mengakses pemberitaan terkait perubahan Dolly melalui instagram maupun facebook dikarenakan keterbatasan teknologi yang dimiliki oleh telepon genggam mereka dan mereka tidak mengetahui juga cara untuk mengaksesnya, bahkan beberapa dari responden tidak memiliki telepon genggam. Sedangkan mayoritas warga justru mengetahuinya melalui media massa konvensional (Koran dan TV), perbincangan warga sekitar, dan sosialisasi langsung dari Pemerintah Kota Surabaya. Melalui hal ini dapat dilihat juga kecenderungan responden dalam berkomu-nikasi dan mengakses informasi lebih kepada komunikasi secara langsung (face to face) dan melalui media massa konvensional. 
Tabel IV.14.

Deskripsi Komponen Afektif Berdasarkan Elemen Identitas

\begin{tabular}{|c|c|c|c|c|c|c|c|c|c|c|}
\hline \multicolumn{3}{|c|}{ Identitas afektif } & \multicolumn{5}{|c|}{ Jawaban Responden } & \multirow{2}{*}{$\begin{array}{c}\text { Total } \\
\text { Frek/ } \\
\%\end{array}$} & \multirow{2}{*}{$\begin{array}{l}\text { Total } \\
\text { Score }\end{array}$} & \multirow[t]{2}{*}{ Mean } \\
\hline & & & STS & TS & $\mathrm{N}$ & $\mathbf{S}$ & SS & & & \\
\hline \multirow[t]{2}{*}{ iafel } & \multirow{2}{*}{$\begin{array}{l}\text { Saya menyetujui bahwa identitas Kota Surabaya } \\
\text { terkenal dengan Dolly. }\end{array}$} & Frek & 0 & 2 & 14 & 61 & 23 & 100 & \multirow[t]{2}{*}{405} & \multirow[t]{2}{*}{4.05} \\
\hline & & $\%$ & 0 & 2 & 14 & 61 & 23 & 100 & & \\
\hline \multirow[t]{2}{*}{ iafe2 } & Saya menyetujui penutupan Lokalisasi Dolly oleh & Frek & 11 & 25 & 16 & 31 & 17 & 100 & \multirow[t]{2}{*}{318} & \multirow[t]{2}{*}{3.18} \\
\hline & Pemerintah Kota Surabaya. & $\%$ & 11 & 25 & 16 & 31 & 17 & 100 & & \\
\hline \multirow[t]{2}{*}{ iafe3 } & Saya menyetujui perubahan Lokalisasi Dolly & Frek & 1 & 3 & 9 & 61 & 26 & 100 & \multirow[t]{2}{*}{408} & \multirow[t]{2}{*}{4.08} \\
\hline & $\begin{array}{l}\text { Surabaya menjadi tempat eduwisata yang terdiri dari } \\
\text { Taman Baca Kawan Kami, Kelompok Usaha } \\
\text { Bersama (KUB), dan Lapangan Futsal karena } \\
\text { mampu memberikan nilai positif bagi para anak } \\
\text { kecil dan remaja di sekitar kawasan eks Lokalisasi } \\
\text { Dolly. }\end{array}$ & $\%$ & 1 & 3 & 9 & 61 & 26 & 100 & & \\
\hline \multirow[t]{2}{*}{ iafe4 } & Saya menyetujui perubahan Lokalisasi Dolly & Frek & 2 & 1 & 16 & 55 & 26 & 100 & \multirow[t]{2}{*}{402} & \multirow[t]{2}{*}{4.02} \\
\hline & $\begin{array}{l}\text { Surabaya menjadi tempat edwisata yang menarik } \\
\text { (Kampung Eduwisata yang terdiri dari Kampung } \\
\text { Pengolahan Rumput Laut (Orumi), Kampung Seni } \\
\text { Mural, Kampung Oleh-oleh (Samijali) dan Kampung } \\
\text { Batik) karena menyimpan banyak sejarah dan } \\
\text { cerita mengenai lokalisasi Dolly. }\end{array}$ & $\%$ & 2 & 1 & 16 & 55 & 26 & 100 & & \\
\hline
\end{tabular}

\begin{tabular}{|c|c|c|c|c|c|c|c|c|c|c|}
\hline \multirow[t]{2}{*}{ iafe5 } & \multirow[b]{2}{*}{$\begin{array}{l}\text { Saya menyetujui perubahan lokalisasi Dolly } \\
\text { Surabaya menjadi tempat eduwisata yang menarik } \\
\text { (Kampung Eduwisata yang terdiri dari Kampung } \\
\text { Pengolahan Rumput Laut (Orumi), Kampung Seni } \\
\text { Mural, Kampung Oleh-oleh (Samijali) dan Kampung } \\
\text { Batik) yang dapat menarik, menghibur dan } \\
\text { memberi pengetahuan wisatawan dari luar daerah } \\
\text { maupun mancanegara tentang pesona eks } \\
\text { lokalisasi Dolly saat ini. }\end{array}$} & Frek & 9 & 24 & 13 & 35 & 19 & 100 & \multirow[t]{2}{*}{331} & \multirow[t]{2}{*}{3.31} \\
\hline & & $\%$ & 9 & 24 & 13 & 35 & 19 & 100 & & \\
\hline \multirow[t]{2}{*}{ iafe6 } & \multirow[b]{2}{*}{$\begin{array}{l}\text { Saya menyetujui perubahan Lokaliaasi Dolly } \\
\text { Surabaya menjadi tempat eduwisata yang menarik } \\
\text { (Kampung Pengolahan Rumput Laut (Orumi), } \\
\text { Kampung Oleh-oleh (Samijali) dan Kampung Batik } \\
\text { berserta banyak Kelompok Usaha Bersama (KUB) } \\
\text { seperti ART Sablon, Tempe Bang Jarwo, produk kue } \\
\text { kering \& katering dan Putat Jaya Craft produksi } \\
\text { sepatu dam sandal) yang dapat membantu dan } \\
\text { menambah perekonomian warga sekitar eks } \\
\text { Lokalisasi Dolly. }\end{array}$} & Frek & 14 & 26 & 17 & 24 & 19 & 100 & \multirow[t]{2}{*}{308} & \multirow[t]{2}{*}{3.08} \\
\hline & & $\%$ & 14 & 26 & 17 & 24 & 19 & 100 & & \\
\hline \multirow[t]{2}{*}{ iafe] } & \multirow[b]{2}{*}{$\begin{array}{l}\text { Saya menyetujui perubahan tentang eks lokalieasi } \\
\text { Dolly Surabaya sebagai upaya pembangunan kembali } \\
\text { Kawasan eks Lokalisasi Dolly oleh Pemerintah Kota } \\
\text { Surabaya merupakan upaya untuk perwujudan dari } \\
\text { perbaikan citra atau gambaran dari Kota } \\
\text { Surabaya. }\end{array}$} & Frek & 11 & 22 & 20 & 30 & 17 & 100 & \multirow[t]{2}{*}{320} & \multirow[t]{2}{*}{3.20} \\
\hline & & $\%$ & 11 & 22 & 20 & 30 & 17 & 100 & & \\
\hline \multicolumn{10}{|c|}{ Rata-rata Komponen Afektif berdasarkan Elemen Identitas } & 3,56 \\
\hline
\end{tabular}


Berdasarkan Tabel IV.14. di atas, nilai rata-rata sikap responden pada komponen afektif yang berdasarkan elemen identitas adalah 3,56 yang menandakan netral, hal ini berarti tingkat afeksi responden pada komponen afektif berdasarkan elemen identitas adalah sedang. Komponen afektif menyangkut masalah emosional subjektif seseorang terhadap suatu objek sikap. Secara umum, komponen ini disamakan dengan perasaan yang dimiliki terhadap sesuatu (Azwar,2016:26). Mayoritas Warga Putat Jaya menyetujui afeksi mereka bahwa identitas Kota Surabaya terkenal dengan Dolly.

Kemudian terkait adanya penutupan Lokalisasi Dolly oleh Pemerintah Kota Surabaya, responden berpendapat netral. Pada komponen afektif berdasarkan elemen identitas ini, sikap Warga Putat Jaya mengenai mengenai City Branding Kota Surabaya melalui Program Revitalisasi eks Lokalisasi Dolly adalah netral. Mayoritas responden menyetujui afeksi mereka mengenai identitas Kota Surabaya terkenal dengan Dolly, responden juga menyetujui adanya penutupan Lokalisasi Dolly oleh Pemerintah Kota Surabaya dan perubahannya saat ini menjadi sebuah Kampung Eduwisata
Tematik. Mayoritas responden menyetujui adanya penutupan dan perubahan eks Lokalisasi Dolly karena dinilai mampu memberikan nilai positif bagi para anak kecil dan remaja di sekitar kawasan eks Lokalisasi Dolly.

Kemudian responden juga menyetujui adanya perubahan eks Lokalisasi Dolly karena menyimpan banyak sejarah dan cerita mengenai lokalisasi Dolly. Selain itu perubahan ini dapat menarik, menghibur dan memberi pengetahuan wisatawan dari luar daerah maupun mancanegara tentang pesona eks lokalisasi Dolly. Kemudian dapat membantu dan menambah perekonomian warga sekitar eks Lokalisasi Dolly dan juga sebagai upaya untuk perwujudan dari perbaikan citra atau gambaran dari Kota Surabaya. Namun pada hal perekonomian pada item ke-6 jumlah skor antara warga yang setuju dan setuju hampir sama tinggi. Pada indikator ini memperoleh 43 jawaban responden dalam kategori setuju dan 40 jawaban responden dalam kategori tidak setuju. Hal ini mengindikasikan bahwa masih ada Warga eks Lokalisasi Dolly yang menggantungkan perekonomiannya dari keberadaan Lokalisasi Dolly yang lama. 
Tabel IV.15.

Deskripsi Komponen Afektif berdasarkan Elemen Komunikasi

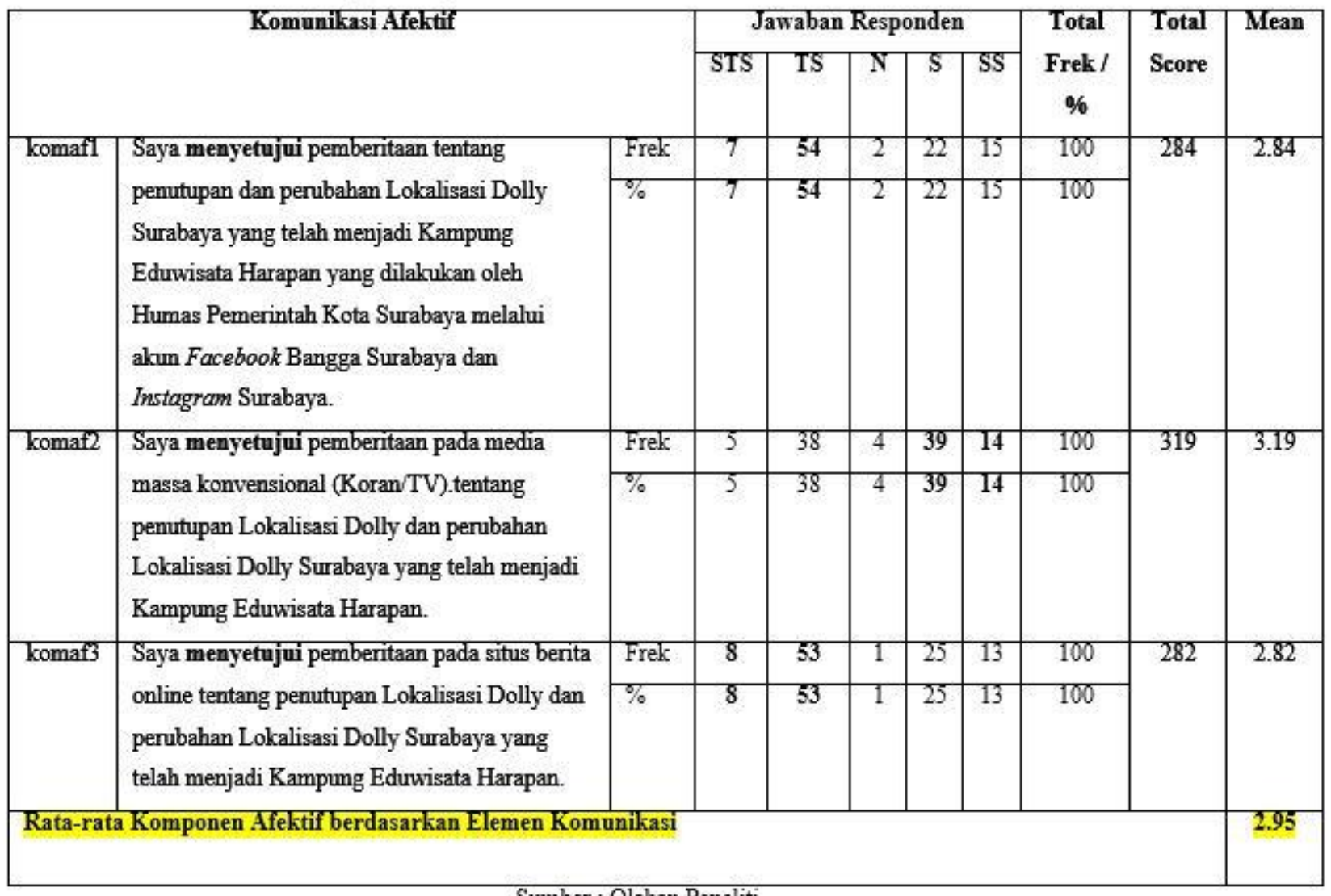

Sumber: Olahan Peneliti

Berdasarkan Tabel IV.15. di atas, nilai rata-rata sikap responden pada komponen afektif yang berdasarkan elemen identitas adalah 2,95 yang menandakan netral. Hal ini berarti tingkat afeksi responden pada komponen afektif berdasarkan elemen komunikasi adalah sedang. Pada bagian komponen afektif berdasarkan elemen komunikasi ini, peneliti tidak menggunakan bentuk komunikasi melalui sosialisasi dari Pemerintah Kota Surabaya maupun perbincangan warga sekitar. Karena peneliti pada bagian ini peneliti ingin melihat persetujuan warga eks Lokalisasi Dolly terhadap pemberitaan yang ada di berbagai media massa. Mayoritas responden tidak menyetujui afeksi mereka terkait pemberitaan adanya perubahan Lokalisasi Dolly Surabaya yang telah menjadi Kampung Eduwisata
Harapan yang dilakukan oleh Humas Pemerintah Kota Surabaya melalui akun Facebook dan Instagram dan dari situs berita online. Karena responden tidak pernah mengakses pemberitaan terkait perubahan Lokalisasi Dolly tersebut maka mereka juga tidak menyetujui pemberitaan yang ada pada media sosial milik Pemerintah Kota Surabaya (instagram dan facebook). Mayoritas dari responden juga tidak pernah mengakses berita terkait perubahan Lokalisasi Dolly melalui situs berita online, sehingga mereka juga cenderung tidak menyetujui pemberitaan yang ada pada situs berita online. Banyak dari responden justru menyetujui pemberitaan yang ada di media massa konvensional (Koran dan TV) karena mereka lebih sering mengakses media konvensional tersebut. 
Tabel IV.16.

Deskripsi Komponen Konatif berdasarkan Elemen Identitas

\begin{tabular}{|c|c|c|c|c|c|c|c|c|c|c|}
\hline \multicolumn{3}{|c|}{ Identitas konatif } & \multicolumn{5}{|c|}{ Jawaban Responden } & \multirow{2}{*}{$\begin{array}{c}\begin{array}{c}\text { Total } \\
\text { Frek } / \\
\%\end{array} \\
100 \\
\end{array}$} & \multirow{3}{*}{$\begin{array}{l}\text { Total } \\
\text { Score } \\
294\end{array}$} & \multirow{3}{*}{$\begin{array}{l}\text { Mean } \\
2.94\end{array}$} \\
\hline ikon1 & Saya akan ikut serta dalam pelatihan yang & Frek & \multirow{2}{*}{$\begin{array}{c}\text { STS } \\
9 \\
9\end{array}$} & $\begin{array}{l}\text { TS } \\
44\end{array}$ & $\frac{N}{5}$ & $\begin{array}{l}5 \\
28\end{array}$ & $\begin{array}{l}\text { SS } \\
14\end{array}$ & & & \\
\hline & $\begin{array}{l}\text { diadakan oleh Pemerintah Kota Surabaya } \\
\text { bersama Gerakan Melukis Harapan (GMH) di } \\
\text { salah satu Kelompok Usaha Bersama (KUB) } \\
\text { yang ada di Kampung Eduwisata Harapan eks } \\
\text { Lokalisasi Dolly Surabaya. }\end{array}$ & $\%$ & & 44 & 5 & 28 & 14 & 100 & & \\
\hline \multirow[t]{2}{*}{ ikon2 } & \multirow{2}{*}{$\begin{array}{l}\text { Saya akan ikut serta menjadi anggota } \\
\text { komunitas (UKM) atau karang taruna dalam } \\
\text { usaha pemberdaayan eks Lokalisasi Dolly } \\
\text { Surabaya di Kampung Eduwisata Harapan. }\end{array}$} & Frek & 9 & 44 & 6 & 26 & 15 & 100 & \multirow[t]{2}{*}{294} & \multirow[t]{2}{*}{2.94} \\
\hline & & $\%$ & 9 & 44 & 6 & 26 & 15 & 100 & & \\
\hline \multirow[t]{2}{*}{ ikon3 } & \multirow{2}{*}{$\begin{array}{l}\text { Saya akan ikut serta dalam mengajak teman- } \\
\text { teman dan sanak keluarga untuk mengikuti } \\
\text { program pelatihan yang diadakan oleh } \\
\text { pemerintah beserta Gerakan Melukis Harapan } \\
\text { (GMH) dan komunitas lainnya di Kampung } \\
\text { Eduwisata Harapan. }\end{array}$} & Frek & 11 & 41 & 6 & 27 & 15 & 100 & \multirow[t]{2}{*}{294} & \multirow[t]{2}{*}{2.94} \\
\hline & & $\%$ & 11 & 41 & 6 & 27 & 15 & 100 & & \\
\hline \multirow[t]{2}{*}{ ikon4 } & \multirow{2}{*}{$\begin{array}{l}\text { Saya akan ikut serta dalam menjaga dan } \\
\text { merawat Lingkungan di Kampung Eduwisata } \\
\text { Harapan eks Lokalisasi Dolly Surabaya untuk } \\
\text { menjaga identitas positif eks Lokalisasi Dolly. }\end{array}$} & Frek & 0 & 4 & 20 & 61 & 15 & 100 & \multirow[t]{2}{*}{387} & \multirow[t]{2}{*}{3.87} \\
\hline & & $\%$ & 0 & 4 & 20 & 61 & 15 & 100 & & \\
\hline \multicolumn{10}{|c|}{ Rata-rata Komponen Konatif berdasarkan Elemen Identitas } & 3.17 \\
\hline
\end{tabular}

Sumber: Olahan Peneliti

Berdasarkan Tabel IV.16. di atas, nilai rata-rata sikap responden pada komponen konatif yang berdasarkan elemen identitas adalah sebesar 3.17 yang menandakan netral. Hal ini berarti tingkat konasi responden pada komponen konatif berdasarkan elemen identitas adalah sedang. Komponen konatif berkaitan dengan bagaimana perilaku atau kecenderungan berperilaku yang ada dalam diri seseorang berkaitan dengan objek sikap yang dihadapinya (Azwar,2016:27).
Mayoritas responden yang merupakan warga yang terdampak dari adanya penutupan Lokalisasi Dolly tidak berkenan dalam pelatihan-pelatihan yang diadakan oleh Pemerintah Kota Surabaya. Secara pribadi mereka yang tidak menyetujui keikutsertaannya dalam pelatihan namun mereka tetap memiliki keinginan tersendiri untuk menjaga dan merawat lingkungan tempat tinggal mereka yang berada di wilayah eks Lokalisasi Dolly.

Tabel IV.17.

Deskripsi Komponen Konatif berdasarkan Elemen Komunikasi

\begin{tabular}{|c|c|c|c|c|c|c|c|c|c|c|}
\hline \multicolumn{3}{|c|}{ Komunikasi Konatif } & \multicolumn{5}{|c|}{ Jawaban Responden } & \multirow{2}{*}{$\begin{array}{c}\text { Total } \\
\text { Frek/ } \\
\%\end{array}$} & \multirow{2}{*}{$\begin{array}{l}\text { Total } \\
\text { Score }\end{array}$} & \multirow[t]{2}{*}{ Mean } \\
\hline & & & STS & TS & $\mathrm{N}$ & $\mathrm{S}$ & SS & & & \\
\hline \multirow{3}{*}{$\begin{array}{l}\text { Kom } \\
\text { kof } 1\end{array}$} & Saya akan ikut serta dalam melakukan & Frek & 7 & 34 & 12 & 31 & 16 & 100 & \multirow[t]{3}{*}{315} & \multirow[t]{3}{*}{3,15} \\
\hline & sosialisasi agar masyarakat luar & & & & & & & & & \\
\hline & $\begin{array}{l}\text { mengetahui tentang perkembangan } \\
\text { keadaan Dolly saat ini. }\end{array}$ & $\%$ & 7 & 34 & 12 & 31 & 16 & 100 & & \\
\hline \multicolumn{10}{|c|}{ Rata-rata Komponen Konatif berdasarkan Elemen Komunikasi } & 3,15 \\
\hline
\end{tabular}


Berdasarkan Tabel IV.17. di atas, nilai rata-rata sikap responden pada komponen konatif yang berdasarkan elemen komunikasi adalah sebesar 3.15 yang menandakan netral. Hal ini berarti tingkat konasi responden pada komponen konatif berdasarkan elemen komunikasi adalah sedang. Mayoritas warga Putat Jaya ikut serta untuk melakukan sosialisasi agar masyarakat luar mengetahui tentang perkembangan keadaan Dolly saat ini. Namun terkait peran aktif warga eks Lokalisasi Dolly untuk mensosialisasikan perubahan Dolly sekarang, belum semuanya warga berkeinginan untuk melakukannya.
Hal ini ditunjukkan dengan jumlah responden pada indikator ini memperoleh 47 jawaban responden dalam kategori setuju dan 41 jawaban responden dalam kategori tidak setuju mengenai konasi mereka, selisih yang dihasilkan antara jawaban setuju dan tidak setuju tidak berbeda jauh. Hal ini juga menunjukan adanya indikasi bahwa belum semua Warga Putat Jaya mau secara aktif ikut melakukan sosialisasi kepada masyarakat luar terkait perubahan Lokalisasi Dolly saat ini.

Tabel IV.18.

Deskripsi Komponen Konatif berdasarkan Elemen Citra

\begin{tabular}{|c|c|c|c|c|c|c|c|c|c|c|}
\hline & Citra Konatif & & & raba & $\operatorname{Resp}$ & nde & & Total & Total & Mean \\
\hline & & & STS & TS & $\mathbf{N}$ & $\mathrm{S}$ & SS & Frek/ & Score & \\
\hline citkonl & Saya cenderung memiliki gambaran positif & Frek & 6 & 28 & 21 & 28 & 17 & 100 & 322 & 3.22 \\
\hline & mengenai upaya pembanguman kembali & $\%$ & 6 & 28 & 21 & 28 & 17 & 100 & & \\
\hline & Kawasan eks Lokalisasi Dolly oleh & & & & & & & & & \\
\hline & Pemerintah Kota Surabaya karena & & & & & & & & & \\
\hline & $\begin{array}{l}\text { memberikan manfaat untuk perekonomian } \\
\text { warga sekitar. }\end{array}$ & & & & & & & & & \\
\hline citkon2 & Saya cenderumg memiliki gambaran positif & Frek & 0 & 1 & 24 & 55 & 20 & 100 & 394 & 394 \\
\hline & mengenai upaya pembanguman kembali & $\%$ & 8 & 1 & 24 & 55 & 30 & 100 & & \\
\hline & Kawasan eks Lokalisasi Dolly oleh & & & & & & & & & \\
\hline & Pemerintah Kota Surabaya karena & & & & & & & & & \\
\hline & memberikan manfaat untuk kehidupan & & & & & & & & & \\
\hline & anak-anak dan remaja yang tinggal di & & & & & & & & & \\
\hline & Kawasan eks Lokalisasi Dolly. & & & & & & & & & \\
\hline citkon3 & Saya cenderumg memiliki gambaran positif & Frek & 7 & 24 & 22 & 30 & 17 & 100 & 326 & 3.26 \\
\hline & mengenai upaya pembangunan kembali & $\%$ & 7 & 24 & 22 & 30 & 17 & 100 & & \\
\hline & nilai Kawasan eks Lokalisasi Dolly oleh & & & & & & & & & \\
\hline & Pemerintah Kota Surabaya karena & & & & & & & & & \\
\hline & memberikan manfaat untuk perbaikan citra & & & & & & & & & \\
\hline & Kota Surabaya. & & & & & & & & & \\
\hline & $50 \mathrm{~m}$ & & & & & & & & & 3,47 \\
\hline
\end{tabular}

Sumber: Olahan Peneliti 
Berdasarkan Tabel IV.18. di atas, nilai rata-rata sikap responden pada komponen konatif yang berdasarkan elemen citra adalah sebesar 3.47 yang menandakan netral. Hal ini berarti tingkat konasi responden pada komponen konatif berdasarkan elemen citra adalah sedang. Citra suatu kota merupakan gambaran yang ada dibenak audiens tentang sebuah kota. Gambaran ini merupakan akumulasi dari pengetahuan (kognitif), pengalaman (konatif) dan keterpaparan melalui berita-berita terhadap kota tersebut. Citra juga merupakan cara audiens melalukan penerjemahan (decoding) sinyal yang dikirimkan oleh produk, layanan dan komunikasi yang dilakukan oleh brand (Yananda, 2014: 57-77).

Mayoritas responden cenderung memiliki gambaran positif mengenai upaya pembangunan kembali Kawasan eks Lokalisasi Dolly oleh Pemerintah Kota Surabaya karena memberikan manfaat untuk perekonomian warga sekitar. Kemudian juga memberikan manfaat untuk kehidupan anakanak dan remaja yang tinggal di Kawasan eks Lokalisasi Dolly serta melalui upaya ini juga dapat memberikan manfaat untuk perbaikan citra Kota Surabaya. Namun pada pernyataan yang berkaitan dengan masalah perekonomian jumlah score pada jawaban yang tidak setuju juga cukup tinggi, sehingga mengindikasikan juga bahwa responden ada yang belum memiliki gambaran positif tentang upaya program revitalisasi karena belum memberikan dampak yang terasa bagi warga eks Lokalisasi Dolly.

Pemaparan pada komponen konatif diatas yang menyebabkan hasil sikap dari komponen konatif menjadi netral yang berarti tingkat konasi warga mengenai City Branding Kota Surabaya melalui Program Revitalisasi eks Lokalisasi Dolly adalah sedang. Sikap yang netral pada komponen konatif ini disebabkan karena pertemuan antara jumlah tingkat konasi yang tinggi namun juga diikuti dengan tingkat konasi yang rendah yang tinggi pula.

\section{Kesimpulan}

Mayoritas responden dalam penelitian ini adalah berjenis kelamin perempuan, dengan umur 18-40 tahun, berpendidikan terakhir SMA, berasal dari daerah Surabaya dan memiliki pekerjaan sebagai Ibu Rumah Tangga (IRT). Dari hasil analisis jawaban responden pada penelitian ini telah menjawab rumusan masalah penelitian yaitu "Bagaimana sikap Warga Putat Jaya mengenai City Branding Kota Surabaya melalui Program Revitalisasi eks Lokalisasi Dolly?". Jawaban dari rumusan masalah ini adalah Warga Putat Jaya khususnya Warga RW 3, RW 11, dan RW 12 yang terdampak dari adanya penutupan Lokalisasi Dolly memiliki kecenderungan bersikap netral terhadap Program Revitalisasi yang dilaksanakan oleh Pemerintah Kota Surabaya. 
Sikap netral merupakan hasil temuan dalam penelitian ini yang berarti Warga Putat Jaya khususnya warga RW 3, RW 11, dan RW 12 memiliki tingkat pengetahuan yang sedang, kemudian tingkat afeksi yang sedang dan tingkat konasi yang sedang mengenai City Branding Kota Surabaya melalui Program Revitalisasi eks Lokalisasi Dolly. Sikap netral Warga Putat Jaya merupakan hasil dari masing-masing komponen sikap yaitu komponen kognitif, komponen afektif, dan komponen afektif yang netral pula. Sikap ini berdasarkan pada elemen-elemen city branding yang terdiri dari elemen identitas, elemen komunikasi, dan elemen citra.

Peneliti melakukan tabulasi silang antara identitas responden dengan sikap Warga Putat Jaya. Tabulasi silang ini dilakukan untuk mengetahui faktor-faktor yang membentuk sikap Warga Putat Jaya. Tabulasi silang yang dilakukan peneliti, faktor-faktor yang mempengaruhi sikap netral Warga Putat Jaya adalah faktor pengalaman pribadi melalui jenis kelamin, usia, agama, asal daerah, dan pekerjaan. Kemudian faktor pengaruh orang yang dianggap penting melalui jenis kelamin, faktor lembaga agama melalui agama, faktor pendidikan terakhir melalui pendidikan terakhir yang dimiliki oleh responden.

\section{Saran}

Untuk penelitian selanjutnya diharapkan peneliti dapat menganalisis sikap, menggunakan pendekatan penelitian kualitatif dengan metode studi kasus atau fenomenologi. Hal ini dilakukan untuk melihat fenomena serupa dari sisi lainnya (mulai dari paradigma, pendekatan, dan metode penelitian). Selain itu, jika hal ini dilakukan akan dapat memperkuat penelitian sebelumnya (jika hasilnya sama) atau memberikan pandangan yang berbeda (jika hasilnya berbeda), sehingga arsip akademisnya pun akan semakin kaya.

Kemudian upaya Pemerintah Kota Surabaya dalam melaksanakan City Branding Kota Surabaya melalui Program Revitalisasi eks Lokalisasi Dolly dikatakan netral. Maksudnya dari netral adalah program revitalisasi ini bukan berarti terbilang sukses, namun juga bukan berarti terbilang tidak sukses. Dalam hal ini Warga Putat Jaya khususnya Warga RW 3, RW 11, dan RW 12 belum merasakan dampak yang signifikan dari upaya pemerintah terutama dalam segi perekonomian mereka. Peneliti berharap alangkah baiknya Pemerintah Kota Surabaya dalam menjalankan program revitalisasi dengan melakukan langkah-langkah konkrit seperti pembenahan secara berkala dan berkelanjutan, seperti melakukan lebih banyak sosialisasi, pendekatan komunikasi persuasif dan beberapa strategi lainnya. 
Dalam melakukan sosialisasi terkait adanya perubahan Lokalisasi Dolly sebaiknya Pemerintah Kota Surabaya melakukan secara langsung atau face-to-face dan secara berkala karena berdasarkan hasil temuan penelitian ini kecenderungan Warga Putat Jaya RW 3, RW 11 dan RW 12 dalam berkomunikasi adalah secara langsung dan media massa yang digunakan adalah media massa konvensional yaitu TV atau Koran. Mayoritas dari warga juga tidak dapat mengakses pemberitaan positif terkait adanya perubahan eks Lokalisasi Dolly melalui Instagram, Facebook dan situs berita online karena keterbatasan teknologi yang dimiliki oleh mereka. Warga patut mengetahui pemberitaan positif ini melalui sosialisasi langsung dari Pemerintah Kota Surabaya karena dapat menambah semangat mereka dalam mengikuti segala pelatihan yang telah diberikan Pemerintah Kota Surabaya sebagai Program Revitalisasi eks Lokalisasi Dolly.

\section{DAFTAR PUSTAKA}

Azwar, Saifuddin. 2016. Sikap Manusia: Teori dan Pengukurannya. Jakarta:

Pustaka Pelajar.

Azwar, Saifuddin. 2003. Reliabilitas dan Validitas. Jakarta: Pustaka Pelajar.

Cutlip, Scott. 2006. Effective Public Relations. Jakarta : Kencana
Effendy, Onong Uchjana. 2003. Ilmu, Teori dan Filsafat Komunikasi. Bandung:

Citra Aditya Bakti.

Kriyantono, Rachmat. 2006. Teknik Praktis Riset Komunikasi. Jakarta: Kencana

Hurlock, Elizabeth. 1980. Psikologi Perkembangan. Jakarta: Penerbit Erlangga

Gozhali, Imam. 2002. Aplikasi Analisis Multivariat dengan Program SPSS.

Semarang : Badan Penerbit Universitas Diponegoro

Purnomo dan Siregar. 1983. Dolly: Membedah dunia pelacuran Surabaya, kasus

$$
\text { Kompleks Pelacuran }
$$

Dolly. Jakarta: Grafiti Pers

Ruslan, Rosady. 2014. Manajemen Public Relations dan Media Komunikasi. Jakarta: PT. Raja Grafindo Persada.

Sari, Betty. 2012. Humas Pemerintah. Yogyakarta: Graha Ilmu Silalahi, Ulber. 2012. Metode Penelitian Sosial. Bandung: PT. Refika Aditama

Wawan, A dan Dewi, M. 2010.Teori dan Pengukuran Pengetahuan, Sikap dan 


\section{Perilaku}

Manusia.Yogyakarta: Nuha Medika.

Yananda, Ummi Salamah. 2014. Branding

Tempat. Membangun Kota, Kabupaten, dan Provinsi berbasis Identitas. Jakarta: Makna Informasi

\section{INTERNET}

https://www.facebook.com/melukisharapan/p osts/957583087651202

http://birohukum.pu.go.id

http://jatimprov.go.id

dollysaiki.com

http://surabaya.go.id/

https://egieligius.wordpress.com/2017/06/22/

dolly-sekarang/

Abidin, Zumrotul (2016). Kampung Wisata di Eks Dolly Belum Bergeliat (2016, 21 Februari).Suara Surabaya [online] diakses pada 20 Januari 2017 $\begin{array}{lll}\text { pukul } & 15.00 \quad \text { dari }\end{array}$ http://www.suarasurabaya.net/prin t_news/Kelana\%20Kota/2016/167 625-Kampung-Wisata-di-Eks-

Dolly-Belum-Bergeliat

Ardianto, Arif (2017). Pemkot Surabaya Terus Dorong UKM Warga Eks Dolly. Berita Jatim [on-line] diakses 18 November 2017 pukul 14.51 dari http://beritajatim.com/ekonomi/29 7125/pemkot_surabaya_terus_dor ong_ukm_warga_eks_dolly.html
Bae/Nur/JPNN (2016).Wajah Baru Eks Lokalisasi Dolly Kini. Radar Surabaya [on-line] diakses pada 20 Januari 2017 pukul 18.46 dari http://m.jpnn.com/news/wajahbaru-eks-lokalisasi-dolly-kini

Fully, Syafi (2014). Wisma Barbara Akan Jadi Tempat Pembuatan Sepatu. Tempo [on-line] diakses 8 September 2017 pukul 17.05 dari https://m.tempo.co/read/news/201 4/09/17/173607503/wismabarbara-akan-jadi- $\quad$ tempatpembuatan-sepatu

Jajeli, Rois. (2016). Risma Bangunkan Dua Lapangan Futsal di Eks Lokalisasi Dolly. Detik [on-line] diakses pada 20 Oktober 2017 pukul 23.32 dari

https://news.detik.com/beritajawa-timur/d-3375149/rismabangunkan-dua-lapangan-futsaldi-eks-lokalisasi-dolly

Muhiddin, Salman (2016). Menelisik Gang Dolly Dua Tahun Pasca Penutupan. Jawa Pos [on-line] diakses pada 3 April 2017 pukul 20.34 dari http://www.jawapos.com/read/201 6/06/30/37173/menelisik-gangdolly-dua-tahun-pasca-penutupan Paskalis, Yohanes (2016.) Kalijodo Dibandingkan dengan Gang Dolly, Ahok: Itu Berbeda. Tempo 
[on-line] diakses pada 9 Februari 2017 pukul 22.40 dari https://m.tempo.co/read/news/201 6/02/16/083745432/kalijododibandingkan-dengan-gang-dollyahok-itu-berbeda

Redaksi[at]detik.com. (2015). 6 Wajah Baru Surabaya Setelah Ditangani Risma. Detik [on-line] diakses 19 Oktober 2017 pukul 23.46 dari https://news.detik.com/berita/234 2853/6-wajah-baru-surabayasetelah-ditangani-risma

Rachmawati, Ira. (2017). Taman Baca Cara Kartono Bangun Mimpi Anakanak di Eks Lokalisasi. Kompas [on-line] diakses pada 19 Oktober 2017 pukul 20.30 dari http://regional.kompas.com/read/2 017/05/19/07491301/taman.baca.c ara.kartono.bangun.mimpi.anakanak.di.eks.lokalisasi.?page $=$ all

Utami, Puji (2014). Ini Asal-usul Nama "Gang Dolly". Kompas [on-line] diakses pada 20 Januari 2017 pukul 17.39 dari http://regional.kompas.com/read/2014/06/18/ 1653354/Ini.Asal -usul.Nama.Gang.Dolly.

\section{PENELITIAN TERDAHULU}

Henny, Ruth. (2017). “Sikap Pengunjung mengenai Event Denpasar Festival 2016 sebagai Branding Kota Denpasar Kreatif Berbasis Budaya". Program Studi Ilmu
Komunikasi Universitas Katolik Widya Mandala Surabaya

Chaerani, Ratu Yulya. (2011). "Pengaruh City Branding Terhadap City Image (Studi Pencitraan Kota Solo: 'The Spirit of Java')" oleh Universitas Sultan Ageng Tirtayasa Serang Banten

\section{SUMBER LAIN}

Data wawancara dengan Adam, Humas Gerakan Melukis Harapan (GMH) pada 17 April 2017

Data wawancara dengan Jarwo Susanto, Penjual Tempe Banga Jarwo, pada 31 Oktober 2017

Data wawancara dengan Jefry, Kasubag Layanan Informasi Bagian Humas Pemerintah Kota Surabaya pada 28 April 2017

Data wawancara dengan Kartono dan Salamah, Pemilik Taman Baca Kawan Kami, pada 9 November 2017

Data wawancara dengan warga eks Lokalisasi Dolly pada 7 September 2017

Data wawancara dengan Tjukup, Kepala RW III Putat Jaya, pada 22 Oktober 2017

Peraturan Menteri Pekerjaan Umum No 18/PRT/M/2010

Undang-Undang Dasar (UUD) 1945 